\title{
Identification and characterization of tsunami deposits off southeast coast of India from the 2004 Indian Ocean tsunami: Rock magnetic and geochemical approach
}

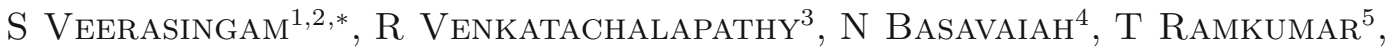 \\ S Venkatramanan ${ }^{6}$ and $\mathrm{K}$ DeEnadayalan ${ }^{4}$ \\ ${ }^{1}$ CSIR - National Institute of Oceanography, Dona Paula, Goa 403 004, India. \\ ${ }^{2}$ Department of Physics, Annamalai University, Annamalainagar 608 002, Tamil Nadu, India. \\ ${ }^{3}$ Faculty of Marine Sciences, Annamalai University, Parangipettai 608 502, Tamil Nadu, India. \\ ${ }_{4}^{4}$ Indian Institute of Geomagnetism, New Panvel, Navi Mumbai 410 218, India. \\ ${ }^{5}$ Department of Earth Sciences, Annamalai University, Annamalainagar 608 002, Tamil Nadu, India. \\ ${ }^{6}$ Institute of Environmental Geosciences, Department of Earth and Environmental Sciences, Pukyong National \\ University, Busan 608737, South Korea. \\ *Corresponding author.e-mail: physicssingam@gmail.com; veerasingams@nio.org
}

The December 2004 Indian Ocean Tsunami (IOT) had a major impact on the geomorphology and sedimentology of the east coast of India. Estimation of the magnitude of the tsunami from its deposits is a challenging topic to be developed in studies on tsunami hazard assessment. Two core sediments $(\mathrm{C} 1$ and C2) from Nagapattinam, southeast coast of India were subjected to textural, mineral, geochemical and rock-magnetic measurements. In both cores, three zones (zone I, II and III) have been distinguished based on mineralogical, geochemical and magnetic data. Zone II is featured by peculiar rockmagnetic, textural, mineralogical and geochemical signatures in both sediment cores that we interpret to correspond to the 2004 IOT deposit. Textural, mineralogical, geochemical and rock-magnetic investigations showed that the tsunami deposit is featured by relative enrichment in sand, quartz, feldspar, carbonate, $\mathrm{SiO}_{2}, \mathrm{TiO}_{2}, \mathrm{~K}_{2} \mathrm{O}$ and $\mathrm{CaO}$ and by a depletion in clay and iron oxides. These results point to a dilution of reworked ferromagnetic particles into a huge volume of paramagnetic materials, similar to what has been described in other nearshore tsunami deposits (Font et al. 2010). Correlation analysis elucidated the relationships among the textural, mineral, geochemical and magnetic parameters, and suggests that most of the quartz-rich coarse sediments have been transported offshore by the tsunami wave. These results agreed well with the previously published numerical model of tsunami induced sediment transport off southeast coast of India and can be used for future comparative studies on tsunami deposits.

\section{Introduction}

A tsunami is one of the most terrifying natural hazards known to humans and has been responsible for tremendous economic and human losses.
Following the recent tsunamis in Indonesia (2004), Chile (2010) and Japan (2011), the risks associated with tsunamis have come into focus. Most tsunamis occur in the marine realm and are associated with large earthquakes (Kremer et al. 2012).

Keywords. Tsunami deposit; texture size; mineral; geochemistry; rock-magnetism. 
Since the Indian Ocean Tsunami (IOT) in 2004, by far the biggest natural catastrophe in human history, the worldwide scientific community has conducted numerous investigations of tsunami deposits to assess tsunami impact. The 26 December 2004 tsunami event devastated several major coastlines in South Asia, including the Tamil Nadu coast, India. The IOT was generated by one of the largest earthquakes in the past 100 years, and its epicentre was located near $3.3^{\circ} \mathrm{N}$ and $95.95^{\circ} \mathrm{E}$ with a magnitude of 9.0 and focal depth of $10 \mathrm{~km}$ (Lay et al. 2005). On the Indian coast, the tsunami involved three waves that arrived at 5 minute intervals. The first wave reached the coast approximately at 9.25 am (Indian local time), some 3 hours after the initial earthquake. In many places, waves ripped large trees out of the ground by the roots and traditional wooden and modern brick and mortar structures off of their pilings or foundations and moved tens to hundreds of meters away from the coast. Tsunami waves have sufficiently high velocities and bed shear stresses to suspend and transport large quantities of sediment (Srinivasalu et al. 2007). Modern studies of tsunamis are often hampered by the lack of information on the frequency and magnitude of past events. In many cases, the unique information that can be used consists of historical records. Therefore, it is often difficult to provide a quantitative assessment of tsunami risks since historical datasets typically cover only a relatively short period of time. Identification of past tsunamis is crucial for risk assessment studies, especially in areas where the historical record is limited or missing (Kortekaas and Dawson 2007). When a tsunami occurs, the momentum of the water flow varies during shuttle movement (landwards and seawards). It is maximal during the main phase of the up-rush and it quickly decreases concomitantly to the reduction of the depth of the flooding water. After a slack phase in the remote areas of the flooding, the backwash begins. Then, the topographically controlled backflow increases. Finally, the backflow decreases as the result of the arrival of the next tsunami wave, and the next cycle begins. Related sedimentary accumulations mainly occur during the up-rush, the slack and beginning of the backwash (if nonerosive) phases. The topography controls the sedimentation of tsunami deposits with the best preservation in depressions (Wassmer et al. 2010). Various aspects of the 2004 IOT onshore deposits on the east and west coasts of India were reported by several researchers (Altaff et al. 2005; Earnest et al. 2005; Jayakumar et al. 2005, 2008; Kumaraguru et al. 2005; Nagendra et al. 2005; Neetu et al. 2005; Narayan et al. 2005; Srinivasalu et al. 2009; Anilkumar et al. 2006; Chaudhary et al. 2006; Hussain et al. 2006, 2010; Mascarenhas 2006;
Shanmugam 2006, 2012; Yeh et al. 2006; Babu et al. 2007; Bahlburg and Weiss 2007; Mascarenhas and Jayakumar 2008; Pari et al. 2008; Vijayalakshmi et al. 2010; Jayakumar 2012). However, studies on offshore tsunami deposits in India are limited (Srinivasalu et al. 2010; Jonathan et al. 2012) and many case studies are necessary to develop a depositional model. Though, tsunami events are rare in nature, scientific documentation helps in coastal management and mitigation measures for the future.

Researchers have used many proxies including geomorphological, stratigraphical, sedimentological, archaeological, anthropological, palynological, numerical model, geochemical, mineralogical, anisotropic magnetic susceptibility, rock magnetic properties, macro- and micropalaeontological evidence to identify historical and palaeotsunami deposits (Goff et al. 2006, 2012; Sawai et al. 2008; Chague-Goff 2010; Font et al. 2010, 2013; Paris et al. 2010; Wassmer et al. 2010; Chague-Goff et al. 2011; Jonathan et al. 2012; Ramirez-Herrera et al. 2012; Smedile et al. 2012; Cuven et al. 2013; Goguitchaichvili et al. 2013; Sugawara et al. 2013). Ranjan et al. (2008) and Srinivasalu et al. (2008) evaluated the metal enrichments from the 26 December 2004 tsunami sediments along the SE coast of India. Srinivasalu et al. (2010) have studied the pre- and post-tsunami shallow deposits off SE coast of India from the 2004 IOT using the geochemical approach. In India, magnetism has been used in environmental studies with strong implications in anthropogenic pollution monitoring (Alagarsamy 2009; Sangode et al. 2010; Venkatachalapathy et al. 2010, 2011a, b, 2013; Blaha et al. 2011; Sandeep et al. 2011), climatic variations and depositional mechanisms (Shankar et al. 1994a, b, 1996; Sangode et al. 2001, 2007; Chauhan et al. 2004; Kumar et al. 2005; Kumaran et al. 2005; Rao et al. 2008; Dessai et al. 2009; Dewangan et al. 2013). However, until now, a magnetic approach to detect tsunami-induced deposits has never been tested in India. Karlin and Abella (1992), used rock magnetic measurements to study the paleoseismic record. The rock magnetic technique has been shown to be a promising tool to identify tsunami deposits in a beach environment (Font et al. 2010) but has never been tested in the case of offshore deposits. In this study, the cost effective rock magnetic techniques are used to identify the magnetic and mineralogical signatures of the 2004 IOT.

This study is the first report on the rock magnetic aspects of tsunami deposits in the continental shelf region of SE coast of India. The aims of the present work are to study (1) the textural, mineralogical and depositional nature of sediments and (2) rock magnetic and geochemical properties of 
tsunami induced deposits in the offshore region. This will help to compare and study the rock magnetic and geochemical nature of sediments of the 2004 tsunami deposits as well as paleo-tsunami deposits near the coastal/lagoon regions along the SE coast of India. Moreover, in Nagapattinam town (the study area), the inundation by tsunami waves was up to $\sim 800 \mathrm{~m}$ compared to the other parts of the coastal areas (Yeh et al. 2006) and the maximum damage (in Tamil Nadu state) in terms of economic and human losses were reported from this region (Srinivasalu et al. 2010).

\section{Study area}

The Nagapattinam coastal segment studied here is located north of Point Calimere region, Bay of Bengal, India. The near-shore bathymetry of this region is relatively steep, straight and parallel to the coast. The tides in this region are semi-diurnal with an average spring range of $0.67 \mathrm{~m}$ and neap range of $0.19 \mathrm{~m}$ (Sanilkumar et al. 2003). The rivers Nandalar, Puravandayanar, Vettar, Uppanar (tributaries of river Cauvery) pass through the granitic terrain and agricultural belt of the Tamil Nadu state before draining into the Bay of Bengal. The coastal stretch is affected by the seasonal monsoon (every year) in the latter half of the year (October-December) (Sarma et al. 1990). The geology around the study area indicates different types of rocks which include alluvium, charnockite, khondalite, garnet-sillimanaite gneiss, pink/grey granite, amphibolites, pyroxenites, and biotite schists, which lie in the southern part of the study area (figure 1a). In addition, the southern part of Cauvery basin (part of Nagapattinam and Karaikal Town) in the peninsular shield is underlain by rocks of Archean age and the coastal tract is covered by younger alluvium and coastal sands (Mohanachandran and Subramanian 1990).

At Nagapattinam, the tsunami overtopped and shattered the sea wall of the fishing harbour; trawlers were tossed ashore; a communication tower crashed, and oil storage tanks suffered erosive damage (Mascarenhas and Jayakumar 2008). The inundation limit and run-up of the study area are illustrated in figure 1(b). This shows more vulnerability in the southern part of Tamil Nadu coast (including the study area) due to its flat topography than the northern part. Backwash flow occurred following the maximum landward inundation of individual tsunami waves as water receded seaward. The study area also witnessed maximum backwash of sediments from land during/after the three major tsunami waves that struck the coastal region (Srinivasalu et al. 2009).

\section{Materials and methods}

\subsection{Sampling}

Several core samples were collected using a gravity core sampler (1.8 m length and $6 \mathrm{~cm}$ diameter) with the help of a fishing trawler boat off Nagapattinam, during October 2008. Two core samples referred here as $\mathrm{C} 1$ and $\mathrm{C} 2$ (from $5 \mathrm{~m}$ and $10 \mathrm{~m}$ water depths) were selected for the present study (figure 2). The water depths and geological coordinates (latitude and longitude) of the sampling points were identified using a single-beam echo-sounder (Odom Hydrotrack) with a Differential Global Positioning System (DGPS - Trimble) housed in a fishing trawler boat along with heave sensor (HS-50). The collected core sediments were sectioned into each $2 \mathrm{~cm}$ slices. Representative samples from each sediment core were stored in labelled self-seal plastic bags and then frozen at $-4^{\circ} \mathrm{C}$ immediately onboard until further analysis.

\subsection{Analytical methods}

The sediment texture such as sand, silt, and clay were measured following the procedure of Ingram (1970). The samples were oven-dried $\left(\sim 100^{\circ}\right)$, powdered in an agate mortar and analysed for major elements such as $\mathrm{SiO}_{2}, \mathrm{Al}_{2} \mathrm{O}_{3}, \mathrm{TiO}_{2}, \mathrm{Fe}_{2} \mathrm{O}_{3}, \mathrm{Na}_{2} \mathrm{O}$, $\mathrm{K}_{2} \mathrm{O}, \mathrm{CaO}, \mathrm{MgO}, \mathrm{P}_{2} \mathrm{O}_{5}$, and $\mathrm{MnO}$ on powdered and pressed pellets with a Thermo Scientific X-ray fluorescence spectrometer. Mineralogical composition was obtained by Fourier transform infrared spectrometry (FTIR). For FTIR analysis, samples were placed in a $\mathrm{KBr}$ disc, which ensures that Lambert-Beer's law is valid. A quantitative determination of the mineral content from various blends was performed by making multi-component analysis of the experimental spectrum using the spectra of each component in the mixture (Bertaux et al. 1998; Veerasingam et al. 2014a). Discrete $2 \mathrm{~cm}$ sediment slices were air-dried at less than $40^{\circ} \mathrm{C}$, gently disaggregated, and then packed in $10 \mathrm{ml}$ polystyrene pots before being subjected to the rock magnetic measurements. The mass of each sample (without the mass of the polystyrene pots) was measured for normalization. Magnetic susceptibility $(\chi)$ measurements were carried out using a Bartington MS-2 magnetic susceptibility meter (with alternating current magnetic field amplitude of $80 \mathrm{~A} / \mathrm{m}$ ) linked to an MS2B dual-frequency sensor $(0.47$ and $4.7 \mathrm{kHz})$. The average of five measurements is presented as mass specific values in $10^{-8} \mathrm{~m}^{3} \mathrm{~kg}^{-1}$ (Dearing 1999). The frequency dependent of susceptibility $\left(\chi_{\mathrm{fd}}\right)$ is calculated using the following formula.

$$
\chi_{\mathrm{fd}} \%=\left(\frac{\left(\chi_{l f}-\chi_{h f}\right)}{\chi_{l f}}\right) \times 100,
$$




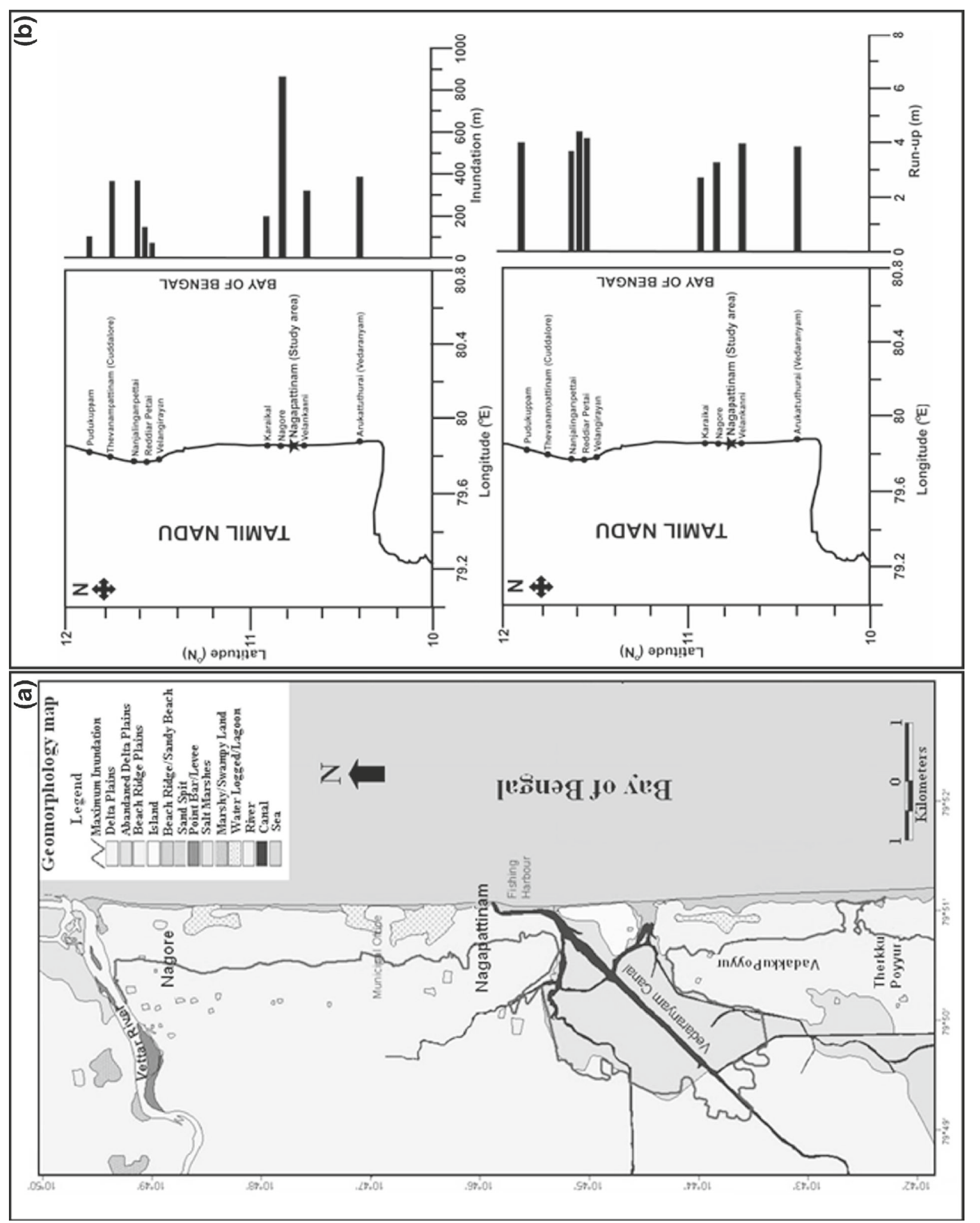




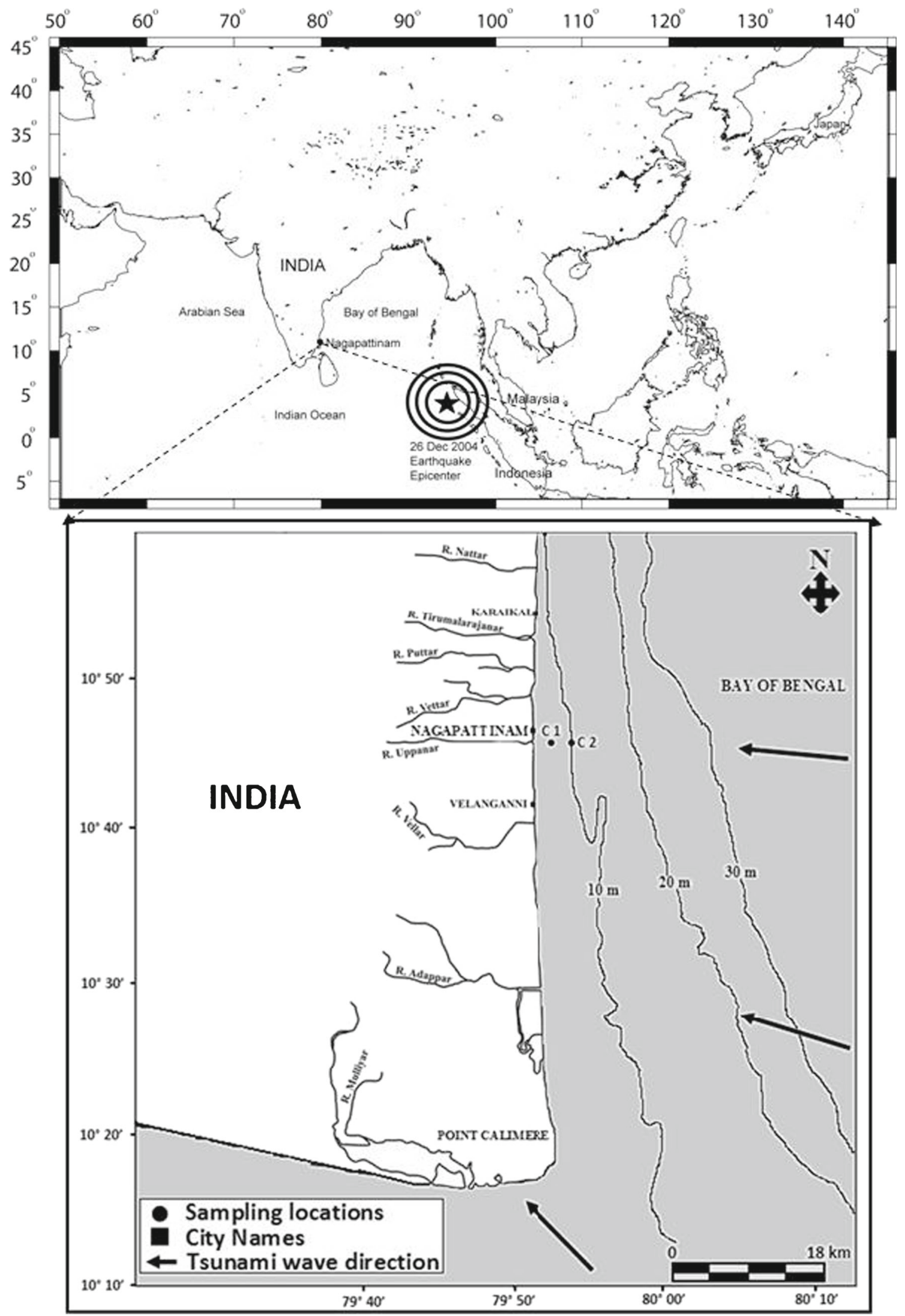

Figure 2. The study area and core sediment locations off southeast coast of India. 
where, $\chi_{l f}$ and $\chi_{h f}$ are the low and high frequency mass specific magnetic susceptibilities. Anhysteretic remanent magnetization (ARM) was imparted in a steady $0.05 \mathrm{mT}$ field superimposed over a decreasing, alternating field (AF) up to $100 \mathrm{mT}$ using a Molspin alternating-field demagnetizer. ARMs are expressed here as anhysteretic susceptibility $\left(\chi_{\mathrm{ARM}}=\mathrm{ARM} /\right.$ strength of the biasing field). All remanent magnetization of the ARMs and IRMs was measured using a Molspin fluxgate spinner magnetometer. Isothermal Remanent Magnetization (IRM) is the remanent magnetization acquired by a sample after exposure to, and removal from, a steady (DC) magnetic field(Walden et al. 1999). IRM was measured for forward fields of $20 \mathrm{mT}, 1 \mathrm{~T}$ and $2 \mathrm{~T}$ and a reverse field of 20,30, 40,60, 80, 100 and $300 \mathrm{mT}$. $\mathrm{IRM}_{2 T}$ is hereafter, referred to as the Saturation Isothermal Remanent Magnetization (SIRM). IRM was imparted with an MMPM9 pulse magnetizer. $\chi_{\mathrm{ARM}} / \mathrm{SIRM}, \chi_{\mathrm{ARM}} / \chi, \mathrm{SIRM} / \chi$, Soft IRM (= SIRM-IRM $-30 \mathrm{mT})$ and Hard IRM (= SIRMIRM $\left._{-300 \mathrm{mT}}\right)$ were measured using forward DC fields. S-ratio $\left(=\right.$ IRM $_{-300} /$ SIRM, being IRM $_{-300}$ the acquired IRM at a backfield of $300 \mathrm{mT}$ ) are also calculated from IRM measurement, using backfield once the SIRM was reached (Thompson and Oldfield 1986). All magnetic measurements are normalized by mass of the sample. The correlation and cluster analyses were carried out to find the relationships among the sediment texture, mineral, geochemical, and rock-magnetic parameters in sediments using Statistical Package for the Social Sciences (SPSS) and Minitab softwares, respectively.

\section{Results and discussion}

\subsection{Sediment texture and mineralogical distribution}

The results of texture size parameters of sediment cores $\mathrm{C} 1$ and $\mathrm{C} 2$ are presented in figure 3 . The average values of sand, silt, and clay contents in $\mathrm{C} 1$ core are $62.43 \%, 8.9 \%$ and $28.7 \%$, while in $\mathrm{C} 2$ core are $59.6 \%, 13.5 \%$, and $26.9 \%$, respectively. Texture size analysis of both sediment cores indicates three zones namely I, II and III. The mean sand content in the $\mathrm{C} 1$ and $\mathrm{C} 2$ cores in the zone II are $82.3 \%$ and $78.4 \%$, respectively. Likewise, the mean silt contents are $4.4 \%$ and $8.9 \%$, where as the mean clay contents are $13.3 \%$ and $12.75 \%$, respectively. Sediment texture size analysis and interpretation of various grain size parameters provide valuable information for both the sources of sediment and hydrodynamic interpretation of the tsunami deposits. The video clips, which were taken during the tsunami that struck Tamil Nadu coast, were first seen to have a direct understanding of the flow process that took place during the event. This video footage showed great plumes of turbid water moving offshore, suggesting that tsunami backwash flow velocities can be remarkably high (Dawson and Stewart 2007). Therefore, the sandy nature of the zone II revealed that the tsunami waves struck the coast and part of the coarse grained fraction was eroded due to returning sea water and deposited in this part. Numerical simulation model (using DHIMIKE software) results for sediment transport during tsunami, showed the total load transport is higher towards the offshore region of Tamil Nadu coast (Jayakumar 2012). The similarity in depositional event in the land area of Nagapattinam as reported by Srinivasalu et al. (2009) and Devi et al. (2013) can be correlated with the sample in the offshore region, which is due to the return flow of tsunami wave, and the distinct subsequent layers (Goff et al. 2004). The recent study of Elakkiya et al. (2013) also describes the assemblage of foraminifera, ostracoda, and their distribution (species including Ammonia beccarii, Globigerina bulloides, Quinqueloculina sp., Spiroloculina orbis, Propontocypris bengalensis, Propontocypris crocata and Phlyctenophora orientalis) in the study area (Nagapattinam), suggesting that these species have been brought by the high energy tsunami waves (2004 IOT deposit). The previous studies (Srinivasalu et al. 2010; Jonathan et al. 2012) provide the supporting evidences of the source of sand deposits in zone II. The zones I and III indicate the domination of clay and silt as compared to zone II, suggesting suspension/deposition of finer particles and reworking of modern process in the near shore environment before and after the major event.

The study of clay mineralogy in marine sediments is closely related to the geology and hydrography of the adjacent land areas (Veerasingam et al. 2014b). The vertical distribution of quartz, feldspar and carbonate in $\mathrm{C} 1$ and $\mathrm{C} 2$ sediment cores is shown in figure 3 . Zone II contains high amount of quartz (C1: 19-23.5\%; C2: 19-22.5\%), feldspar (C1: 17-21\%; C2: 17.5-20.5\%) and carbonate (C1: $8.4-9.6 \%$; C2: $12.3-13 \%)$. Zone I and III of sediment cores are characterised by relatively lower mineral content than zone II, indicating the strong influence of detrital input from the continent. The high concentrations of carbonate in zone II suggest a high-energy environment, where the input of calcareous shells from the land/beach is due to the tsunami return flow (Salem 2009). In the case of the 1755 tsunami deposit of the Boca do Rio estuary, Portugal, textural and mineralogical characteristics between the base and the top of the tsunami 

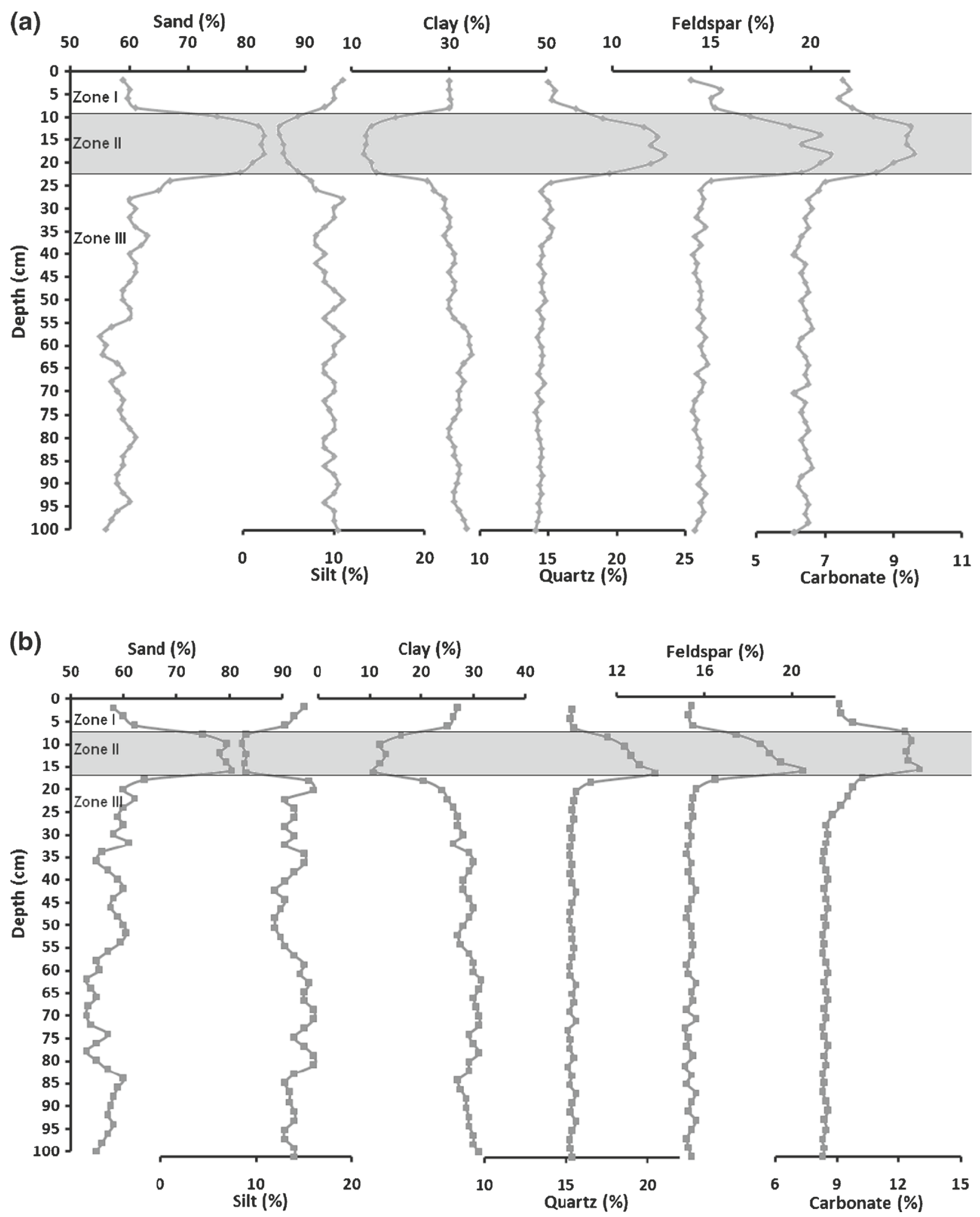

Figure 3. Down core profiles of texture size and minerals for sediment cores (a) C1 and (b) C2.

layer suggest the imprint of run-up and backwash currents derived from a unique wave (Font et al. 2013). Based on the India Meteorological Department (IMD) dataset, there were no catastrophic events such as tsunami and storms between January 2005 (after 2004 IOT) and October 2008 (sampling date) occurring in this region. According to the numerical model (Jayakumar 2012) and IMD data, the prevalence of allochthonous elements including sand and quartz in zone II, might be derived from an adjoining source area during the tsunami backwash. 


\subsection{Geochemical elements}

The geochemical process in the coastal region and the effect of tsunami waves on the overall distribution process is evaluated using vertical distribution of geochemical elements. The vertical distribution of major geochemical elements in sediment cores is given in figure 4. Zones I and III present similar geochemical values while zone II is characterised by an abrupt shift in geochemical composition of both sediment cores. Geochemical analyses indicate that the zone II has lower amount of $\mathrm{Al}$ rich silt/clay than the zones I and III. These differences could reflect changes in the source energy of the depositional environment or transport mechanisms. The higher amount of $\mathrm{Ti}, \mathrm{Si}, \mathrm{Fe}, \mathrm{K}$, and $\mathrm{Ca}$ in zone II compared with the underlying and overlying clayey silt can be partly attributed to the higher occurrence of sand content as opposed to slit and clay content. The enrichment of $\mathrm{TiO}_{2}, \mathrm{SiO}_{2}, \mathrm{Fe}_{2} \mathrm{O}_{3}, \mathrm{~K}_{2} \mathrm{O}$, and $\mathrm{CaO}$ and depletion of $\mathrm{Al}_{2} \mathrm{O}_{3}, \mathrm{Na}_{2} \mathrm{O}, \mathrm{MgO}, \mathrm{P}_{2} \mathrm{O}_{5}$, and $\mathrm{MnO}$ in zone II might be attributed to the tsunami event. $\mathrm{Al}_{2} \mathrm{O}_{3}$ shows a negative correlation with $\mathrm{SiO}_{2}$ and $\mathrm{CaO}$ in zone II, which is explained by the dilution of terrigenous material (clays) within huge volumes of nearshore sand brought by the tsunami wave (Srinivasalu et al. 2010; Font et al. 2013). Ca reflects the amount of carbonates, which is mainly produced under marine conditions, whereas Ti is enriched in tropical soils and is relatively inert against diagenetic processes (Ramirez-Herrera et al. 2012). The previous geochemical studies on Nagapattinam beach sediments (Seralathan et al. 2006; Sujatha et al. 2008), exhibit the same set of geochemical compositions and similar concentrations, which support the fact that the sands found in the tsunami deposit come from nearshore.

\subsection{Magnetic concentration dependent parameters}

Magnetic susceptibility $(\chi)$ measurements generally reflect physical changes in the depositional environment in relation to climate and environmental changes. $\chi$ is directly proportional to the quantity and grain size of ferromagnetic and/or ferrimagnetic minerals in a sample (Thompson and Oldfield 1986; Verosub and Roberts 1995), which is sensitive to diamagnetic and paramagnetic signals when ferrimagnetic concentrations are low (Robertson et al. 2003). Saturation Isothermal Remanent Magnetisation (SIRM) mainly reflects the combined concentration of ferrimagnetick (i.e., magnetite and maghemite) and imperfect anti-ferromagnetic (i.e., hematite and goethite) minerals. SIRM responds primarily to the concentration of ferrimagnetic mineral, but unlike $\chi$ it is not affected by diamagnetic and paramagnetic minerals (Rao et al. 2008). $\chi_{\mathrm{ARM}}$ is particularly sensitive to the concentration of stable single domain ferrimagnetic grains (Oldfield 1991). Data of concentration dependent magnetic parameters $\left(\chi\right.$, SIRM, and $\left.\chi_{\mathrm{ARM}}\right)$ for $\mathrm{C} 1$ and $\mathrm{C} 2$ are shown in figure $5(\mathrm{a}$ and $\mathrm{b})$. The ranges of magnetic susceptibility for $\mathrm{C} 1$ and $\mathrm{C} 2$ sediment cores are $31.8-55.8 \times 10^{-8} \mathrm{~m}^{3} \mathrm{~kg}^{-1}$ (average $46.77 \times$ $10^{-8} \mathrm{~m}^{3} \mathrm{~kg}^{-1}$ ) and $30.8-49.7 \times 10^{-8} \mathrm{~m}^{3} \mathrm{~kg}^{-1}$ (average $42.41 \times 10^{-8} \mathrm{~m}^{3} \mathrm{~kg}^{-1}$ ), respectively. Values of SIRM vary between 290-488.09 $\times 10^{-5} \mathrm{Am}^{2}$ $\mathrm{kg}^{-1}$ (average $355.35 \times 10^{-5} \mathrm{Am}^{2} \mathrm{~kg}^{-1}$ ) and 256.52-361.94 × $10^{-5} \mathrm{Am}^{2} \mathrm{~kg}^{-1}$ (average 318.19 $\times$ $10^{-5} \mathrm{Am}^{2} \mathrm{~kg}^{-1}$ ), respectively. Likewise, $\chi_{\mathrm{ARM}}$ values for $\mathrm{C} 1$ and $\mathrm{C} 2$ sediment cores varied from $0.41-$ $0.64 \times 10^{-5} \mathrm{~m}^{3} \mathrm{~kg}^{-1}$ (average $0.56 \times 10^{-5} \mathrm{~m}^{3} \mathrm{~kg}^{-1}$ ) and $0.43-0.69 \times 10^{-5} \mathrm{~m}^{3} \mathrm{~kg}^{-1}$ (average $0.54 \times$ $10^{-5} \mathrm{~m}^{3} \mathrm{~kg}^{-1}$ ), respectively. Zone I and III show similar $\chi$, SIRM, and $\chi_{\text {ARM }}$ values while the tsunami deposit (zone II) is characterised by a sudden decrease of $\chi\left(\mathrm{C} 1: \sim 32.7 \times 10^{-8} \mathrm{~m}^{3} \mathrm{~kg}^{-1}\right.$, C2: $\left.\sim 31.9 \times 10^{-8} \mathrm{~m}^{3} \mathrm{~kg}^{-1}\right)$, SIRM (C1: $\sim 297.8$ $\left.\times 10^{-5} \mathrm{Am}^{2} \mathrm{~kg}^{-1}, \mathrm{C} 2: \sim 263.7 \times 10^{-5} \mathrm{Am}^{2} \mathrm{~kg}^{-1}\right)$ and $\chi_{\text {ARM }}\left(\mathrm{C} 1: \sim 0.47 \times 10^{-5} \mathrm{~m}^{3} \mathrm{~kg}^{-1}, \mathrm{C} 2: \sim 0.45\right.$ $\times 10^{-5} \mathrm{~m}^{3} \mathrm{~kg}^{-1}$ ) indicative of a very low contribution of ferrimagnetic minerals or the high contribution of paramagnetic/diamagnetic minerals into the sediment matrix. In zone II, the measured susceptibility of weak ferrimagnetic samples, in which calcium carbonate and silica or quartz are abundant, is reduced by diamagnetism. Depletion of magnetic susceptibility in zone II, matches the low values of magnetic susceptibility associated with quartz rich sand contents observed recently by Devi et al. (2013) in the Nagapattinam coast. The magnetic susceptibility values in Nagapattinam beach sediments (Devi et al. 2013), exhibit the same set of minerals and in similar concentrations. Thus, paramagnetic minerals (transfer of these minerals from the beach area had taken place during the backwash of huge tsunami waves) have contributed significantly to the magnetic susceptibility in zone II sediment samples.

\subsection{Magnetic grain size distribution}

The magnetic grain sizes (domain structures) are classified into four: stable single domain (SSD), pseudo-single domain (PSD), multi-domain (MD) and super-paramagnetic (SP). The domain structure plays an important role in the magnetic properties of ferro- or ferrimagnetic minerals (Dearing et al. 1996). The values of magnetic grain size dependent parameters $\left(\chi_{\mathrm{fd}} \%, \chi_{\mathrm{ARM}} / \chi\right.$, $\chi_{\mathrm{ARM}} / \mathrm{SIRM}$ and $\left.\mathrm{SIRM} / \chi\right)$ for sediment cores $\mathrm{C} 1$ and $\mathrm{C} 2$ are shown in figure $5(\mathrm{a}$ and $\mathrm{b})$. Frequency 


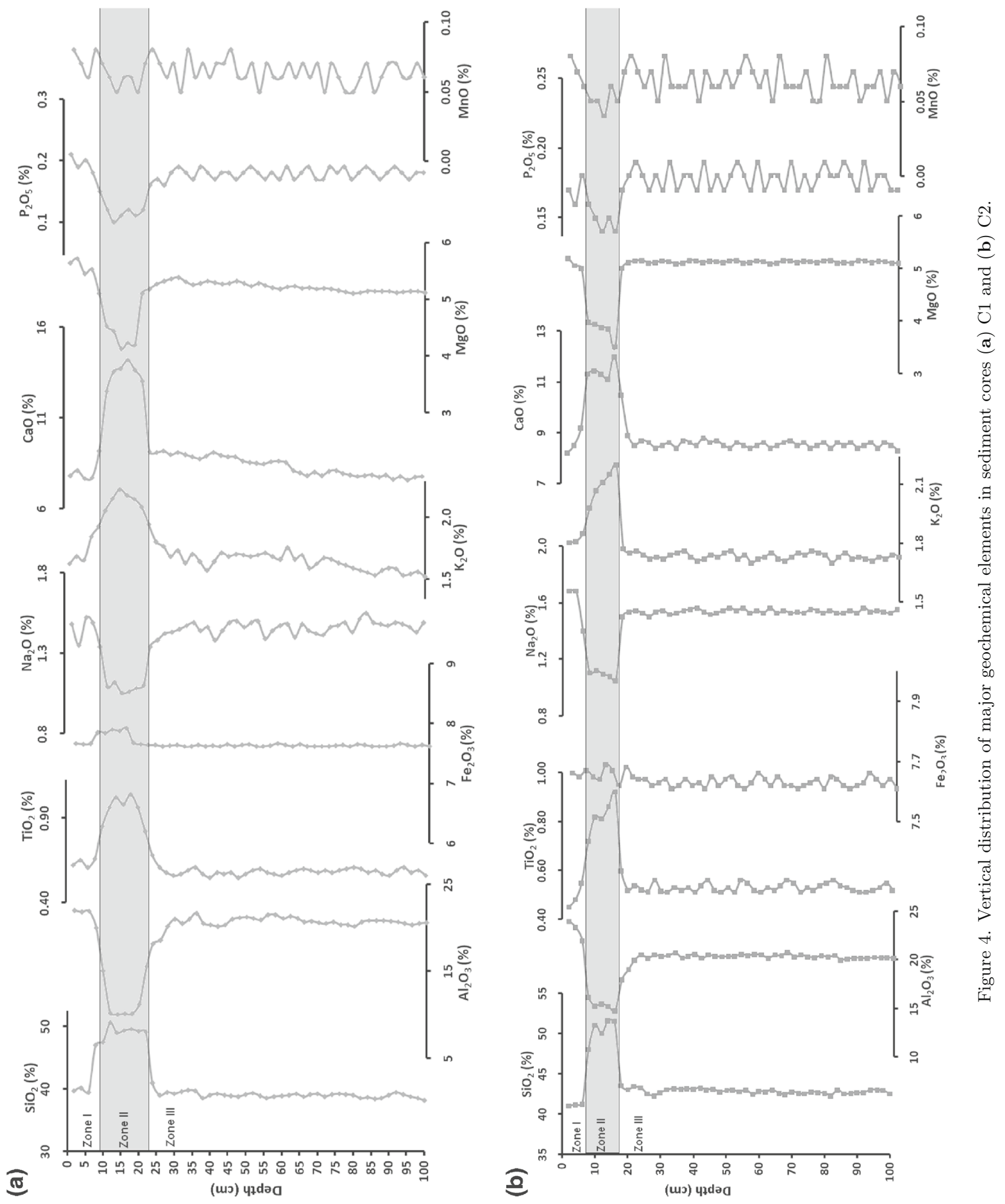




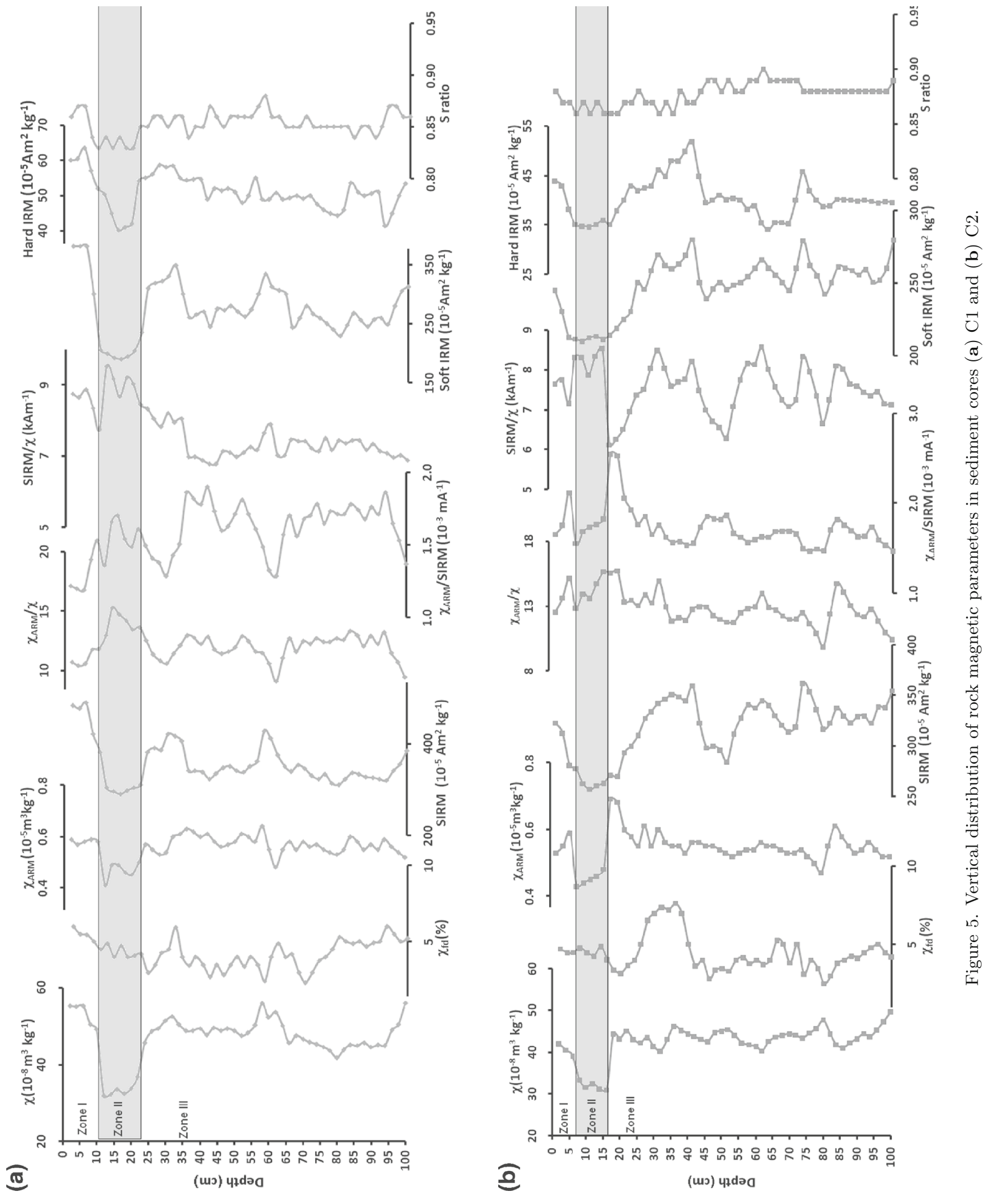


dependent susceptibility is an indicator of the presence of very fine SP ferromagnetic grains. As coarse magnetic particles, such as MD and SSD grains, are frequency independent, they show similar susceptibility values at low and high frequencies. $\chi \mathrm{fd} \%<4 \%$ means no SP and dominant $\mathrm{MD}$ and SSD grains in sediment while, $\chi \mathrm{fd} \%>10 \%$ reflects high content of pedogenic SP grains (Dearing 1999). Mean values of $\chi_{\mathrm{fd}} \%$ of zones I, II and III are lesser than $10 \%$ and therefore indicate that superparamagnetic minerals are not dominant in these samples. $\chi_{\mathrm{ARM}}$ is particularly sensitive to the presence of small grains (SD and small PSD grains), whereas $\chi$ and SIRM are relatively more sensitive to the presence of larger grains (large PSD and MD grains) (Evans and Heller 2003). Thus, the ratio $\chi_{\mathrm{ARM}} / \chi$ is used to assess the relative variations in the amount of fine versus coarse magnetic grains in geological materials (Verosub and Roberts 1995). Peters and Dekkers (2003) also pointed out that $\chi_{\mathrm{ARM}} / \chi$ values decrease with increasing magnetite grains sizes. Higher $\chi_{\text {ARM }} /$ SIRM values reflect a larger fraction of fine SD-PSD grains that respond more effectively to $\chi_{\mathrm{ARM}}$ than SIRM (Maher 1988). $\chi_{\mathrm{ARM}} / \chi$ and $\mathrm{SIRM} / \chi$ are sensitive to the finer magnetic grain sizes (above the threshold for stable SD behaviour), while $\chi_{\mathrm{ARM}} / \mathrm{SIRM}$ is sensitive to the coarser (PSD to MD) grain sizes (King et al. 1982). A $\chi_{\mathrm{ARM}} / \mathrm{SIRM}$ value of $<20 \times 10^{-5} \mathrm{Am}^{-1}$ indicates MD + PSD grains. Values between 20 and $90 \times 10^{-5} \mathrm{Am}^{-1}$ suggest coarse MD grains (Dearing et al. 1997). All grain size parameters show continuous and smooth variations along the entire stratigraphic sequences except for zone II, which might be due to the significant contribution of coarse grained mixture of MD and SSD particles.

\subsection{Mineralogy dependent parameters}

Magnetic mineralogy parameters such as Soft IRM, Hard IRM and $\mathrm{S}$ ratio are shown in figure 5(a and $\mathrm{b})$. Minerals with low coercivity values are termed magnetically 'soft' while those with high values are 'hard'. Ferromagnetic and ferrimagnetic minerals have lower coercivity values than anti-ferromagnetic minerals (Kruiver and Passier 2001). The soft IRM parameter is a measure of concentration of soft magnetic minerals (e.g., magnetite) while hard IRM reflects hard magnetic minerals (e.g., hematite and goethite). The S-ratio is a useful parameter for distinguishing magnetic mineral type. $\mathrm{S}$ ratio values close to one indicate the preponderance of the soft magnetic minerals, whereas values close to zero indicate the abundance of the hard magnetic minerals. The profiles of $\mathrm{S}$ ratio in both sediment cores reveal more or less uniform distribution throughout the length. All mineralogy dependent parameters indicate the abundance of ferromagnetic minerals with minor amount of canted anti-ferromagnetic minerals in zones I and III.

\subsection{Provenance of tsunami deposits}

Rock magnetic analysis is a useful tool in studies dealing with sediment provenance. The minor or trace magnetic components can carry key environmental information because their characteristics, or magnetic signature, vary according to their source and depositional history (Maher et al. 2009; Holden et al. 2011). Moreover, sensitive magnetic measurements can be
(1) Pre-tsunami condition

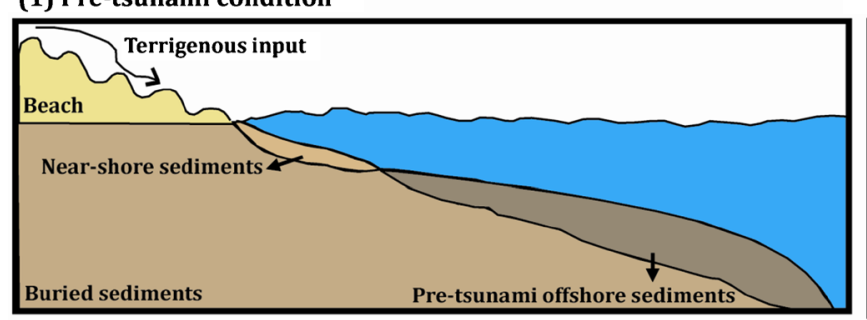

(3) Tsunami return flow

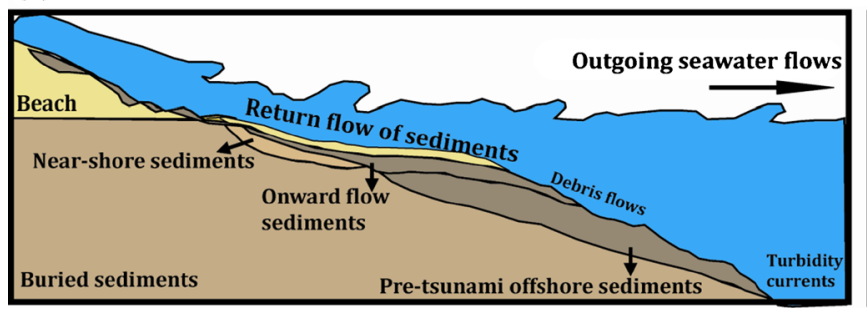

(2)Tsunami landward flow

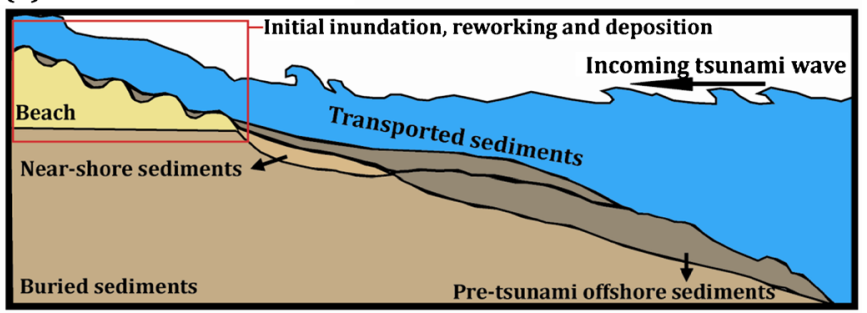

(4) Post-tsunami condition

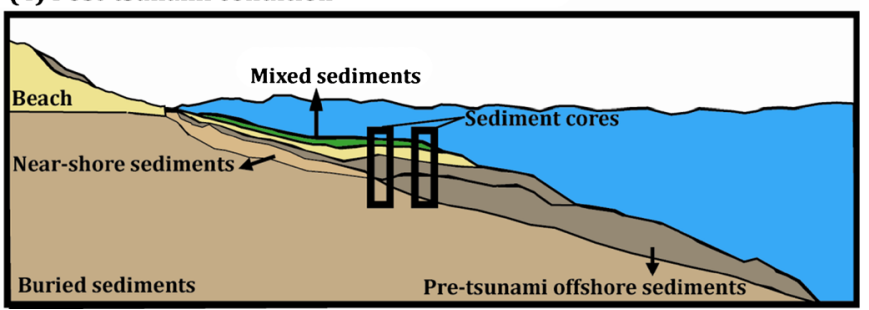

Figure 6. Depositional sequence of sediments (during the 2004 Indian Ocean Tsunami) indicating their characters in sediment cores collected off Nagapattinam, SE coast of India. 
made relatively cheaply and rapidly compared with other mineralogical, geochemical and foraminiferal analyses. Based on tsunami video clippings, numerical model, textural, geochemical, mineralogical and magnetic results in core sediments, depositional data were generated for Nagapattinam coast (figure 6). This deposition model showed four progressive steps including pre-tsunami stage, tsunami stage (wave propagation landward and inundation), depositional stage (backwash flows and related gravity driven processes seaward) and post-tsunami stage. This model also showed that the backwash current has transported and deposited sediments from a landward source during the tsunami event.

Results of the Pearson's correlation coefficient matrix for the overall sediment textural, mineralogical, geochemical and rock-magnetic parame- ters of both $\mathrm{C} 1$ and $\mathrm{C} 2$ sediment cores are given in table 1. In order to compare and interpret the tsunami deposits zone with the other zones, we performed the Pearson's correlation coefficient analysis for textural, mineralogical, geochemical, and rock-magnetic parameters. The results of correlation coefficients of all measured parameters with respect to magnetic susceptibility have been illustrated in figure 7. Magnetic susceptibility is negatively correlated with sand contents of all three zones of both sediment cores, whereas a positive correlation is observed between magnetic susceptibility and silt and clay contents. It confirms that iron oxides in zone II are essentially contained in the detrital fraction (clay and silt) and dilution of huge volume of dia- to paramagnetic sands.

Magnetic susceptibility positively correlated with SIRM, Soft IRM, Hard IRM, and S-ratio

Table 1. Pearson correlation coefficient matrix of textural, mineralogical, geochemical and rock-magnetic parameters in sediment cores $C 1$ and C2.

\begin{tabular}{|c|c|c|c|c|c|c|c|c|c|c|}
\hline & $\chi$ & $\chi_{\mathrm{fd}} \%$ & $\chi_{\mathrm{ARM}}$ & SIRM & $\chi_{\mathrm{ARM}} / \chi$ & $\begin{array}{c}\chi_{\mathrm{ARM}} / \\
\text { SIRM }\end{array}$ & $\operatorname{SIRM} / \chi$ & $\begin{array}{l}\text { Soft } \\
\text { IRM }\end{array}$ & $\begin{array}{l}\text { Hard } \\
\text { IRM }\end{array}$ & $\begin{array}{c}\mathrm{S} \\
\text { ratio }\end{array}$ \\
\hline \multicolumn{11}{|c|}{ Sediment core $\mathrm{C} 1$} \\
\hline Sand & -0.36 & -0.15 & 0.25 & -0.07 & 0.42 & 0.20 & 0.33 & -0.08 & 0.30 & -0.28 \\
\hline Silt & 0.29 & 0.22 & -0.27 & 0.21 & -0.40 & -0.33 & -0.02 & 0.24 & -0.05 & 0.23 \\
\hline Clay & 0.33 & 0.08 & -0.19 & -0.01 & -0.36 & -0.10 & -0.42 & -0.01 & -0.37 & 0.25 \\
\hline $\mathrm{SiO}_{2}$ & -0.09 & -0.24 & 0.14 & 0.23 & 0.15 & -0.11 & 0.48 & 0.21 & 0.25 & -0.10 \\
\hline $\mathrm{Al}_{2} \mathrm{O}_{3}$ & 0.31 & 0.03 & 0.17 & 0.02 & -0.13 & 0.08 & -0.37 & -0.06 & -0.11 & 0.06 \\
\hline $\mathrm{TiO}_{2}$ & -0.44 & -0.06 & -0.01 & -0.14 & 0.34 & 0.10 & 0.32 & -0.14 & -0.16 & -0.14 \\
\hline $\mathrm{Fe}_{2} \mathrm{O}_{3}$ & 0.37 & -0.43 & 0.24 & 0.54 & -0.17 & -0.32 & 0.42 & 0.53 & 0.69 & 0.19 \\
\hline $\mathrm{Na}_{2} \mathrm{O}$ & -0.12 & 0.41 & 0.05 & -0.26 & 0.14 & 0.24 & -0.28 & -0.36 & -0.25 & -0.28 \\
\hline $\mathrm{K}_{2} \mathrm{O}$ & 0.21 & -0.45 & 0.03 & 0.44 & -0.17 & -0.37 & 0.46 & 0.47 & 0.47 & 0.09 \\
\hline $\mathrm{CaO}$ & 0.43 & -0.44 & 0.31 & 0.54 & -0.17 & -0.28 & 0.34 & 0.49 & 0.65 & 0.21 \\
\hline $\mathrm{MgO}$ & 0.46 & -0.35 & 0.33 & 0.48 & -0.19 & -0.22 & 0.19 & 0.46 & 0.67 & 0.18 \\
\hline $\mathrm{P}_{2} \mathrm{O}_{5}$ & 0.00 & 0.27 & 0.09 & -0.13 & 0.07 & 0.16 & -0.22 & -0.17 & -0.12 & -0.18 \\
\hline $\mathrm{MnO}$ & 0.11 & -0.32 & 0.08 & 0.15 & -0.04 & -0.09 & 0.13 & 0.15 & 0.28 & -0.02 \\
\hline Quartz & 0.15 & -0.09 & 0.10 & 0.42 & -0.08 & -0.29 & 0.48 & 0.34 & 0.63 & -0.18 \\
\hline Feldspar & 0.10 & -0.02 & -0.08 & 0.34 & -0.14 & -0.35 & 0.43 & 0.32 & 0.08 & 0.17 \\
\hline Carbonate & -0.16 & -0.02 & -0.11 & 0.19 & 0.03 & -0.24 & 0.51 & 0.23 & 0.20 & 0.03 \\
\hline \multicolumn{11}{|c|}{ Sediment core C2 } \\
\hline Sand & -0.14 & -0.04 & 0.64 & -0.50 & 0.54 & 0.67 & -0.34 & -0.41 & 0.29 & -0.60 \\
\hline Silt & 0.06 & 0.00 & -0.03 & 0.05 & -0.05 & -0.01 & 0.01 & -0.15 & -0.45 & 0.08 \\
\hline Clay & 0.14 & 0.05 & -0.77 & 0.60 & -0.64 & -0.82 & 0.42 & 0.59 & -0.10 & 0.70 \\
\hline $\mathrm{SiO}_{2}$ & 0.01 & 0.06 & 0.37 & -0.22 & 0.27 & 0.37 & -0.19 & -0.28 & 0.27 & -0.42 \\
\hline $\mathrm{Al}_{2} \mathrm{O}_{3}$ & -0.07 & 0.25 & -0.72 & 0.48 & -0.51 & -0.76 & 0.43 & 0.52 & 0.23 & 0.44 \\
\hline $\mathrm{TiO}_{2}$ & 0.17 & -0.18 & 0.25 & -0.22 & 0.10 & 0.28 & -0.28 & -0.38 & -0.24 & -0.16 \\
\hline $\mathrm{Fe}_{2} \mathrm{O}_{3}$ & 0.07 & -0.21 & 0.29 & -0.34 & 0.17 & 0.39 & -0.32 & -0.47 & -0.21 & -0.24 \\
\hline $\mathrm{Na}_{2} \mathrm{O}$ & 0.22 & -0.05 & -0.33 & 0.22 & -0.34 & -0.31 & 0.07 & 0.28 & 0.14 & 0.20 \\
\hline $\mathrm{K}_{2} \mathrm{O}$ & 0.05 & -0.03 & 0.44 & -0.21 & 0.31 & 0.41 & -0.20 & -0.22 & 0.00 & -0.26 \\
\hline $\mathrm{CaO}$ & 0.00 & -0.12 & 0.62 & -0.45 & 0.45 & 0.67 & -0.38 & -0.51 & -0.16 & -0.40 \\
\hline $\mathrm{MgO}$ & 0.02 & 0.06 & -0.49 & 0.12 & -0.37 & -0.40 & 0.09 & 0.19 & 0.21 & 0.27 \\
\hline $\mathrm{P}_{2} \mathrm{O}_{5}$ & -0.08 & -0.09 & 0.06 & -0.03 & 0.09 & 0.04 & 0.02 & -0.06 & 0.03 & -0.04 \\
\hline $\mathrm{MnO}$ & 0.00 & -0.07 & 0.12 & -0.34 & 0.08 & 0.27 & -0.28 & -0.27 & -0.15 & -0.09 \\
\hline Quartz & -0.01 & -0.06 & 0.41 & -0.45 & 0.30 & 0.52 & -0.37 & -0.47 & -0.29 & -0.13 \\
\hline Feldspar & -0.05 & -0.19 & 0.56 & -0.39 & 0.44 & 0.60 & -0.30 & -0.39 & -0.20 & -0.32 \\
\hline Carbonate & -0.05 & -0.19 & 0.73 & -0.63 & 0.56 & 0.84 & -0.50 & -0.74 & -0.20 & -0.50 \\
\hline
\end{tabular}




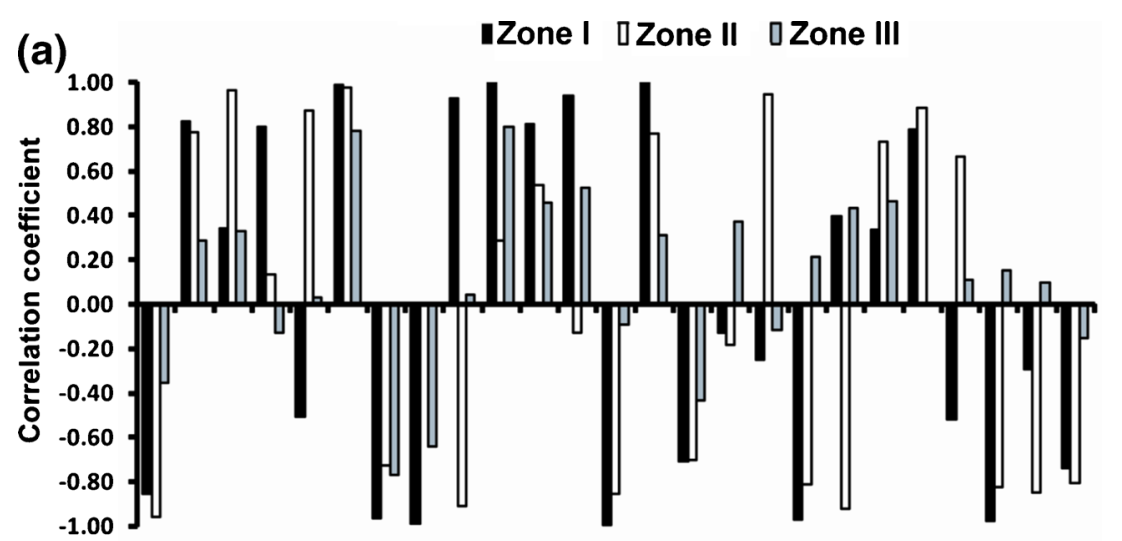

(b)

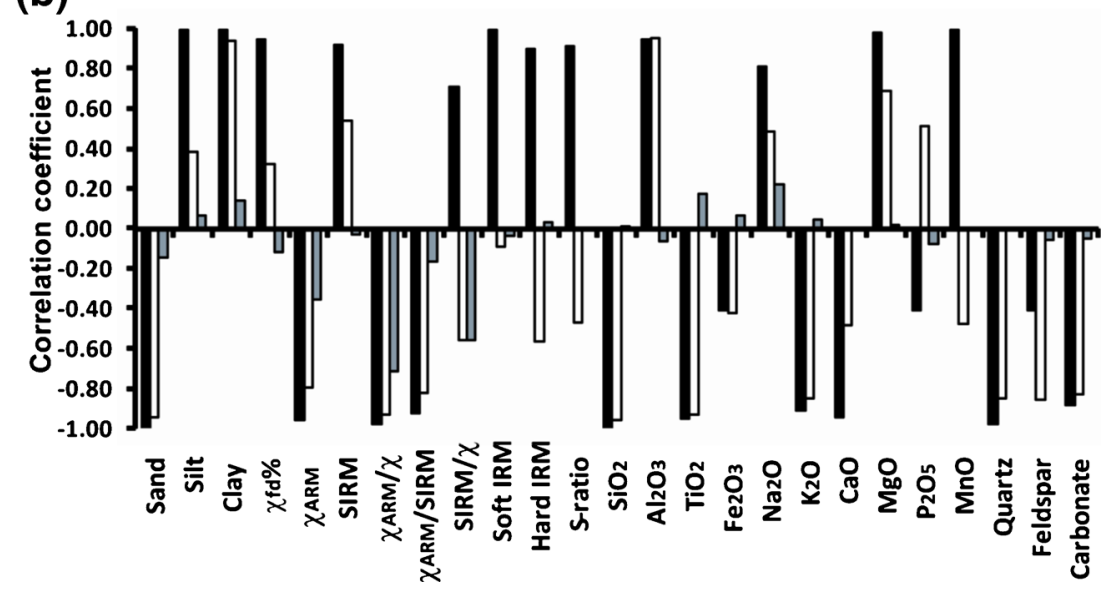

Figure 7. Pearson correlation coefficients of magnetic susceptibility versus a set of textural, mineralogical, geochemical and rock-magnetic parameters in sediment cores (a) $\mathrm{C} 1$ and (b) $\mathrm{C} 2$.

indicates that the variation of $\chi$ is mainly governed by the presence of ferrimagnetic minerals (Venkatachalapathy et al. 2010). Magnetic susceptibility $(\chi)$ show a negative correlation with $\chi_{\mathrm{ARM}} / \chi, \chi_{\mathrm{ARM}} / \mathrm{SIRM}$, and $\mathrm{SIRM} / \chi$ suggesting that magnetic susceptibility may correspond to a change in magnetic particle content (Venkatachalapathy et al. 2011a, b). Magnetic susceptibility showed a positive correlation with $\chi_{\mathrm{fd}}$ in core $\mathrm{C} 1$ and a negative correlation in core $\mathrm{C} 2$. This suggests that $\chi_{\mathrm{fd}}$ measurements are unreliable due to the low signal to noise ratio that results from the weak magnetic susceptibility values (Mohamed et al. 2011).

$\chi$ positively correlated with $\mathrm{Al}_{2} \mathrm{O}_{3}, \mathrm{Na}_{2} \mathrm{O}, \mathrm{MgO}$, $\mathrm{P}_{2} \mathrm{O}_{5}$ and $\mathrm{MnO}$, but negatively correlated with $\mathrm{SiO}_{2}, \mathrm{TiO}_{2}, \mathrm{Fe}_{2} \mathrm{O}_{3}, \mathrm{~K}_{2} \mathrm{O}$ and $\mathrm{CaO}$, revealed that the transfer of minerals from the beach area had taken place during the backwash of huge tsunami waves (Srinivasalu et al. 2010). The correlation results also showed that the deposition of magnetic minerals, geochemical and texture size of sediments in zone II is due to the erosion and transportation of sandy sediments from the backwash of the tsunami wave and the finer particles are being washed away to deeper regions.

\section{Conclusion}

The 2004 Indian Ocean tsunami has left significant sand deposits along the coastal, near-shore, and offshore regions of Tamil Nadu. The study of these deposits provides a better understanding of the effects of the tsunami on offshore region. The offshore region has the potential to preserve tsunami deposits in shallow coastal regions depending on the local topographical conditions. The textural, mineral, geochemical, and rock-magnetic results of sediment cores collected off Nagapattinam, on the southeast coast of India were effectively used to identify the depositional sequence in areas affected by the tsunami. In the two studied cores, the textural, mineralogical, and geochemical results of the zone II sediments, assumed here to represent the 2004 IOT, indicate enrichment in quartz, which is interpreted to result from the erosion and transportation of the inland area and beach by the 
tsunami wave. This interpretation is compatible with the previous numerical model for tsunami induced sediment transport off the southeast coast of India. The rock magnetic properties of zone II show low values of magnetic susceptibility interpreted to result in the dilution of iron oxides from rework terrestrial sediment (silt and clay) into huge volume of dia- to paramagnetic materials (sand and shell fragments). Such an interpretation is comforted by our correlation analysis. This work confirms that the rock magnetic techniques, being fast and cost effective, can be used as a promising tool to identify the tsunami induced deposits in offshore regions.

\section{Acknowledgements}

This study was supported by the Ministry of Earth Sciences, Government of India project MoES/11$\mathrm{MRDF} / 1 / 13 / \mathrm{P} / 07$. The authors are thankful to the Director, Faculty of Marine Sciences, Annamalai University, Tamil Nadu and Director, Indian Institute of Geomagnetism, Mumbai, for providing all the facilities. This paper is greatly benefited from the constructive reviews and valuable suggestions of Dr Eric Font and Associate Editor Dr Pawan Dewangan.

\section{References}

Alagarsamy R 2009 Environmental magnetism and application in the continental shelf sediments of India; Marine Environ. Res. 68 49-58.

Altaff K, Sugumaran J and Naveed M D S 2005 Impact of tsunami on meiofauna of Marina beach, Chennai, India; Curr. Sci. 89 34-38.

Anilkumar N, Sarma Y V B, Babu K N, Sudhakar M and Pandey P C 2006 Post-tsunami oceanographic conditions in southern Arabian Sea and Bay of Bengal; Curr. Sci. $90421-427$.

Babu N, Suresh Babu D S and Mohan Das P N 2007 Impact of tsunami on texture and mineralogy of major placer deposit in southwest coast of India; Environ. Geol. 52 71-80.

Bahlburg H and Weiss R 2007 Sedimentology of the December 26, 2004 Sumatra tsunami deposits in eastern India (Tamil Nadu) and Kenya; Int. J. Earth Sci. 96 1195-1209.

Bertaux J, Frohlich F and Ildefonse Ph 1998 Multicomponent analysis of FTIR spectra: Quantification of amorphous and crystallized mineral phases in soils and sediments; J. Sedim. Res. 69 440-447.

Blaha U, Basavaiah N, Deenadayalan K, Borole D V and Mohite R D 2011 Onset of industrial pollution recorded in Mumbai mudflat sediments, using integrated magnetic, chemical, ${ }^{210} \mathrm{~Pb}$ dating, and microscopic methods; Env. Sci. Technol. 45 689-692.

Chague-Goff C 2010 Chemical signatures of palaeotsunamis: A forgotten proxy; Marine Geol. 271 67-71.
Chague-Goff C, Schneider J-L, Goff J R, Dominey-Howes D and Strotz L 2011 Expanding the proxy toolkit to help identify past events - Lessons from the 2004 Indian Ocean Tsunami and the 2009 South Pacific Tsunami; Earth Sci. Rev. 107 107-122.

Chaudhary D R, Ghosh A and Patolia J S 2006 Characterisation of soils in the tsunami affected coastal areas of Tamil Nadu for agronomic rehabilitation; Curr. Sci. 91 99-104.

Chauhan O S, Patil S K and Suneethi J 2004 Fluvial influx and weathering history of the Himalayas since Last Glacial Maxima - Isotopic, sedimentological and magnetic records from the Bay of Bengal; Curr. Sci. 84 509-515.

Cuven S, Paris R, Falvard S, Miot-Noirault E, Benbakkar M, Schneider J-L and Billy I 2013 High-resolution analysis of a tsunami deposit: Case-study from the 1755 Lisbon tsunami in southwestern Spain; Marine Geol. 337 98-111.

Dawson A G and Stewart I 2007 Tsunami deposits in the geological record; Sedim. Geol. 200 166-183.

Dearing J A 1999 Susceptibility; In: Environmental magnetism: A practical guide (eds) Walden J, Oldfield $\mathrm{F}$ and Smith J P, Quaternary Research Association, Cambridge, pp. 35-62.

Dearing J A, Bird P M, Dann R J and Benjamin S F 1997 Secondary ferrimagnetic minerals in Welsh soils: A comparison of mineral magnetic detection methods and implications for mineral formation; Geophys. J. Int. 124 $228-240$.

Dearing J A, Dann R J L, Hay K, Lees J A, Loveland P J, Maher B A and O'Grady K 1996 Frequency-dependent susceptibility measurements of environmental materials; Geophys. J. Int. 124 228-240.

Dessai D V G, Nayak G N and Basavaiah N 2009 Grain size, geochemistry, magnetic susceptibility: Proxies in identifying sources and factors controlling distribution of metals in a tropical estuary, India; Estuarine Coast. Shelf Sci. 85 307-318.

Devi K, Vijaya Lakshmi C S, Raicy M C, Srinivasan P, Murthy S G N, Hussain S M, Buynevich I and Nair R R 2013 Integrated approach of assessing sedimentary characteristics of onshore sand deposits on the Velankanni coast, Tamil Nadu, India: Sheds light on extreme wave event signatures; J. Coast. Conser. 17 167-178.

Dewangan P, Basavaiah N, Badesab F K, Usapkar A, Mazumdar A, Joshi R and Ramprasad T 2013 Diagenesis of magnetic minerals in a gas hydrate/cold seep environment off the Krishna-Godavari, Bay of Bengal; Marine Geol. 340 57-70.

Earnest A, Rajendran C P, Rajendran K, Anu R, Arun G M and Mohan P M 2005 Near field observations on the co-seismic deformation associated with the 26 December 2004 Andaman-Sumatra earthquake; Curr. Sci. 89 1237-1244.

Elakkiya P, Hussain S M and Elumalai K 2013 Distribution of foraminifera and ostracoda in the Kameshwaram coast, Nagapattinam, south India: Implications for recognition of overwash/extreme wave event deposits; In: On a sustainable future of the earth's natural resources (ed.) Ramkumar Mu (Heidelberg, New York, Dordrecht London: Springer), pp. 139-148.

Evans M E and Heller F 2003 Environmental magnetism: Principles and applications of enviromagnetics; Academic Press, Oxford.

Font E, Nascimento C, Omira R, Baptista M A and Silva P F 2010 Identification of tsunami induced deposits using numerical modelling and rock magnetism techniques: A case study of the 1755 Lisbon tsunami in Algarve, Portugal; Phys. Earth Planet. Interiors 182 187-198. 
Font E, Veiga-Pires C, Pozo M, Nave S, Costas S, Munoz F R, Abad M, Simoes N and Duarte S 2013 Benchmarks and sediment source(s) of the 1755 Lisbon tsunami deposit at Boca do Rio estuary; Marine Geol. 343 1-14.

Goff J, Chague-Goff C, Nichol S, Jaffe B and DomineyHowes D 2012 Progress in palaeotsunami research; Sedim. Geol. 243 70-88.

Goff J, Dudley W C, deMaintenon M J, Cain G and Coney J P 2006 The largest local tsunami in $20^{\text {th }}$ century Hawaii; Marine Geol. 226 65-79.

Goff J R, Wells A, Chague-Goff C, Nichol S L and Devoy R J N 2004 The elusive AD 1826 tsunami, South Westland, New Zealand; New Zealand Geographer 60 28-39.

Goguitchaichvili A, Ramirez-Herrera M T, Calvo-Rathert M, Reyes B A, Carrancho A, Caballero C, Bautista F and Contreras J M 2013 Magnetic fingerprint of tsunamiinduced deposits in the Ixtapa-Zihuatanejo area, Western Mexico; Int. Geol. Rev. 55 1462-1470.

Holden V J C, Worsley A T, Booth C A and Lymbery G 2011 Characterisation and sediment source linkages of intertidal sediment of the UK's north Sefton coast using magnetic and textural properties: Findings and limitations; Ocean Dyn. 61 2157-2179.

Hussain S M, Krishnamurthy R, Gandhi S M, Ilayaraja K, Ganesan P and Mohan S P 2006 Micropaleontological investigations of tsunamigenic sediments of Andaman Islands; Curr. Sci. 91 1655-1667.

Hussain S M, Mohan S P and Jonathan M P 2010 Ostracoda as an aid in identifying 2004 tsunami sediments: A report from SE coast of India; Natural Hazards 55 513-522.

Ingram R L 1970 Procedures in sedimentary petrology; Wiley, New York, USA.

Jayakumar S 2012 A numerical study on tsunami induced sediment transport in vicinity of a submarine canyon off southeast coast of India; In: ICEC 2012: Proceedings of the Fourth International Conference on Estuaries and Coasts, Water Resources University, Hanoi, Vietnam, pp. 148-155.

Jayakumar S, Ilangovan D, Naik K A, Gowthaman R, Tirodkar G, Naik G N, Ganeshan P, ManiMurali R, Michael G S, Ramana M V and Bhattacharya G C 2005 Run-up and inundation limits along southeast coast of India during the 26 December 2004 Indian Ocean tsunami; Curr. Sci. 88 1741-1743.

Jayakumar S, Naik K A, Ramanamurthy M V, Ilangovan D, Gowthaman R and Jena B K 2008 Post-tsunami changes in the littoral environment along the southwest coast of India; J. Environ. Manag. 89 35-44.

Jonathan M P, Srinivasalu S, Thangadurai N, RajeshwaraRao N, Ram-Mohan V and Narmatha T 2012 Offshore depositional sequence of 2004 tsunami from Chennai, SE coast of India; Natural Hazards 62 1155-1168.

Karlin R and Abella S E B 1992 Paleoearthquakes in the Puget Sound Region recorded in sediments from Lake Washington, USA; Science 258 1617-1620.

King J W, Banerjee S K, Marvin J and Ozdemir A 1982 A comparison of different magnetic methods for determining the relative grain size of magnetite in natural samples: Some results from lake sediments; Earth Planet. Sci. Lett. 59 404-419.

Kortekaas S and Dawson A G 2007 Distinguishing tsunami and storm deposits: An example from Martinhal, SW Portugal; Sedim. Geol. 200 208-221.

Kremer K, Simpson G and Girardclos S 2012 Giant Lake Geneva tsunami in AD 563; Nature Geosci. 5 756-757.

Kruiver P P and Passier H F 2001 Coercivity analysis of magnetic phases in sapropel S1 related to variations in redox conditions, including an investigation of the S-ratio; Geophys. Geochem. Geosys. 21063.

Kumar A A, Rao V P, Patil S K, Kessarkar P M and Thamban M 2005 Rock magnetic records of the sediments of the eastern Arabian Sea: Evidence for late Quaternary climatic change; Marine Geol. 220 59-82.

Kumaraguru A K, Jayakumar K, Wilson J J and Ramakitinan C M 2005 Impact of the Tsunami of 26 December 2004 on the Coral Reef Environment of Gulf of Mannar and Palk Bay in the southeast coast of India; Curr. Sci. 89 1729-1741.

Kumaran K P N, Nair K M, Shindikar M, Limaye R B and Padmalal D 2005 Stratigraphical and palynological appraisal of the Late Quaternary mangrove deposits of the west coast of India; Quat. Res. 64 418-431.

Lay T, Kanamori H, Ammon C J, Nettles M, Ward S N, Aster R C, Beck S L, Bilek S L, Brudzinski M R, Butler R, DeShon H R, Ekstrom G, Satake K and Sipkin S 2005 The great Sumatra-Andaman earthquake of 26 December 2004; Science 308 1127-1132.

Maher B A 1988 Magnetic properties of some synthetic submicron magnetite; Geophys. J. 94 83-96.

Maher B A, Watkins S J, Brunskill G, Alexander J and Fielding C R 2009 Sediment provenance in a tropical fluvial and marine context by magnetic 'fingerprinting' of transportable sand fractions; Sedimentology $\mathbf{5 6}$ $841-861$.

Mascarenhas A 2006 Extreme events, intrinsic land forms and human kind: Post-tsunami scenario along Nagore-Velankanni coast, Tamil Nadu, India; Curr. Sci. 90 1195-1201.

Mascarenhas A and Jayakumar S 2008 An environmental perspective of post-tsunami scenario along the coast of Tamil Nadu, India: Role of sand dunes and forests; J. Environ. Manag. 89 24-34.

Mohamed K J, Rey D, Rubio B, Dekkers M J, Roberts A P and Vilas F 2011 Onshore offshore gradient in reductive early diagenesis in coastal marine sediments of the Ria de Vigo, Northwest Iberian Peninsula; Cont. Shelf Res. 31 433-447.

Mohanachandran G and Subramanian V 1990 Texture, mineralogy and elemental composition of sediments along the southeast coast of India; Indian J. Marine Sci. 19 $128-132$.

Nagendra R, Kamalakannan B V, Sajith C, Sen G, Reddy A N and Srinivasalu S 2005 A record of foraminiferal assemblage in tsunami sediments along Nagappattinam Coast, Tamil Nadu; Curr. Sci. 89 1947-1952.

Narayan J P, Sharma M L and Maheshwari B K 2005 Runup and inundation pattern developed during the Indian Ocean Tsunami of December 26, 2004 along the coast of Tamilnadu (India); Gondwana Res. 8 611-616.

Neetu S, Suresh I, Shankar R, Shankar D, Shenoi S S C, Shetye S R, Sundar D and Nagarajan B 2005 Comment on "The Great Sumatra-Andaman Earthquake of 26 December 2004"; Science 3101431.

Oldfield F 1991 Environmental magnetism - a personal perspective; Quat. Sci. Rev. 10 73-85.

Pari Y, Ramanamurthy M V, Jayakumar S, Subramanian B R and Ramachandran S 2008 Morphological changes at Vellar estuary, India - Impact of the December 2004 tsunami; J. Environ. Manag. 89 45-57.

Paris R, Fournier J, Poizot E, Etienne S, Morin J, Lavigne F and Wassmer P 2010 Boulder and fine sediment transport and deposition by the 2004 tsunami in Lhok Nga (western Banda Aceh, Sumatra, Indonesia): A coupled offshoreonshore model; Marine Geol. 268 43-54.

Peters C and Dekkers M J 2003 Selected room temperature magnetic parameters as a function of mineralogy, 
concentration and grain size; Phys. Chem. Earth 28 659-667.

Ramanamurthy M V, Reddy N T, Pari Y, Usha Tune and Mishra P 2012 Mapping of seawater inundation along Nagapattinam based on field observations; Natural Hazards 60 161-179.

Ramirez-Herrera M-T, Lagos M, Hutchinson I, Kostoglodov V, Machain M L, Caballero M, Goguitchaichvili A, Aguilar B, Chague-Goff C, Goff J, Ruiz-Fernandez A-C, Ortiz M, Nava H, Bautista F, Lopez G I and Quintana P 2012 Extreme wave deposits on the Pacific coast of Mexico: Tsunamis or storms? - A multi-proxy approach; Geomorphology 139-140 360-371.

Ranjan R K, Ramanathan A, Singh G and Chidambaram S 2008 Assessment of metal enrichments in tsunamigenic sediments of Pichavaram mangroves, south-east coast of India; J. Environ. Monit. Assess. 147 389-411.

Rao V P, Kessarkar P M, Patil S K and Ahmad S M 2008 Rock magnetic and geochemical record in a sediment core from the eastern Arabian Sea: Diagenetic and environmental implications during the late Quaternary; Paleogeogr. Palaeoclimatol. Palaeoecol. 270 46-52.

Robertson D J, Taylor K G and Hoon S R 2003 Geochemical and mineral magnetic characterisation of urban sediment particulates, Manchester, UK; Appl. Geochem. 18 269-282.

Salem E-S M 2009 Paleo-tsunami deposits on the Red sea beach, Egypt; Arabian J. Geosci. 2 185-197.

Sandeep K, Shankar R and Krishnaswamy J 2011 Assessment of suspended particulate pollution in the Bhadra river catchment, Southern India: An environmental magnetic approach; Env. Earth Sci. 62 625-637.

Sangode S J, Sinha R, Phartiyal B, Chauhan O S, Mazari R K, Bagati $T$ N, Suresh N, Mishra S, Kumar R and Bhattacharjee P 2007 Environmental magnetic studies on some Quaternary sediments of varied depositional settings in the Indian subcontinent; Quat. Int. 159 $102-118$.

Sangode S J, Suresh N and Bagati T N 2001 Godavari source in the Bengal fan sediments: Results from magnetic susceptibility dispersal pattern; Curr. Sci. $\mathbf{8 0}$ 660-664.

Sangode S J, Vhatkar K, Patil S K, Meshram D C, Pawar N J, Gudadhe S S, Badekar A G and Kumaravel V 2010 Magnetic susceptibility distribution in the soils of Pune metropolitan region: Implications to soil magnetometry of anthropogenic loading; Curr. Sci. 98 516-527.

Sanilkumar V, Mandal S and Ashokkumar K 2003 Estimation of wind speed and wave height during cyclones; Ocean Eng. 30 2239-2253.

Sarma V V B, Murty V S N and Rao D P 1990 Distribution of cyclone heat potential in the Bay of Bengal; Indian J. Marine Sci. 19 102-106.

Sawai Y, Fujii Y, Fujiwara O, Kamataki T, Komatsubara J, Okamura Y, Satake K and Shishikura M 2008 Marine incursions of the past 1500 years and evidence of tsunamis at Suijin-numa, a coastal lake facing the Japan Trench; The Holocene 18 517-528.

Seralathan P, Srinivasalu S, Ramanathan A L, Rajamanikam G V, Nagendra R, Singarasubramanian S R, Mukesh M V and Manoharan K 2006 Post-tsunami sediment characterisation of Tamil Nadu coast; In: 26th December 2004 tsunami: Causes, effects, remedial measures (eds) Rajamanikam G V, Subramaniyam B R, Baba M, Elango R and Prithviraj M, Pre-and Post-tsunami Disaster Management - A Geoscientific Perspective (New Delhi: New Academic Publishers), pp. 59-82.

Shankar R, Thompson R and Galloway R B 1994a Sediment source modelling: Unmixing of artificial magnetisation and natural radioactivity measurements; Earth Planet. Sci. Lett. 126 411-420.

Shankar R, Subba Rao K V and Kolla V 1994b Magnetic susceptibility studies of surficial sediments from the deep Arabian Sea; J. Geol. Soc. India 43 159-167.

Shankar R, Thompson R and Prakash T N 1996 Estimation of heavy and opaque mineral contents of beach and offshore placers using rock magnetic techniques; Geo. Marine Lett. 16 313-318.

Shanmugam G 2006 The tsunamite problem; J. Sedim. Res. $76718-730$.

Shanmugam G 2012 Process-sedimentological challenges in distinguishing paleo-tsunami deposits; Natural Hazards 63 5-30.

Smedile A, De Martini P M and Pantosti D 2012 Combining inland and offshore paleotsunamis evidence: The Augusta Bay (eastern Sicily, Italy) case study; Natural Hazards and Earth Syst. Sci. 12 2557-2567.

Srinivasalu S, Jonathan M P, Thangadurai N and Rammohan V 2010 A study on pre- and post-tsunami deposits off SE coast of India from the 2004 Indian Ocean tsunami: A geochemical approach; Natural Hazards $\mathbf{5 2}$ 391-401.

Srinivasalu S, Rajeshwara-Rao N, Thangadurai N, Jonathan M P, Roy P D, Rammohan V and Saravanan P 2009 Characteristics of 2004 tsunami deposits of northern Tamil Nadu coast, India; Boletin de la Sociedad Geologica Mexicana 61 111-118.

Srinivasalu S, Thangadurai N, Jonathan M P, ArmstrongAltrin J S, Ayyamperumal T and Ram-Mohan V 2008 Evaluation of trace-metal enrichments from the 26 December 2004 tsunami sediments along the southeast coast of India; Environ. Geol. 53 1711-1721.

Srinivasalu S, Thangadurai N, Switzer A D, Rammohan V and Ayyamperumal T 2007 Erosion and sedimentation in Kalpakkam (N Tamil Nadu, India) from the 26th December 2004 tsunami; Marine Geol. 240 65-75.

Sugawara D, Imamura F, Goto K, Matsumoto H and Minoura K 2013 The 2011 Tohoku-oki earthquake tsunami: Similarities and difference to the 869 Jogan tsunami on the Sendai Plain; Pure Appl. Geophys. 170 831-843.

Sujatha C H, Aneeshkumar N and Renjith K R 2008 Chemical assessment of sediment along the coastal belt of Nagapattinam, Tamil Nadu, India, after the 2004 tsunami; Curr. Sci. 95 382-385.

Thompson R and Oldfield F 1986 Environmental Magnetism; Allen \& Unwin, London.

Veerasingam S, Venkatachalapathy $R$ and Ramkumar $T$ 2014a Historical environmental pollution trend and ecological risk assessment of trace metals in marine sediments off Adyar estuary, Bay of Bengal, India; Environ. Earth Sci. 71 3963-3975.

Veerasingam S, Venkatachalapathy R and Ramkumarm T 2014 b Distribution of clay minerals in marine sediments off Chennai, Bay of Bengal, India: Indicators of sediment sources and transport processes; Int. J. Sedim. Res. (in press).

Venkatachalapathy R, Veerasingam S, Basavaiah N and Ramkumar T 2010 Comparison between petroleum hydrocarbon concentrations and magnetic properties in Chennai coastal sediments, Bay of Bengal, India; Marine Petrol. Geol. 27 1927-1935.

Venkatachalapathy R, Veerasingam S, Basavaiah N, Ramkumar T and Deenadayalan K 2011a Environmental magnetic and petroleum hydrocarbons records in sediment cores from the north east coast of Tamilnadu, Bay of Bengal, India; Marine Pollution Bull. 62 681-690. 
Venkatachalapathy R, Veerasingam S, Basavaiah N, Ramkumar T and Deenadayalan K 2011b Environmental magnetic and geochemical characteristics of Chennai coastal sediments, Bay of Bengal, India; J. Earth Syst. Sci. $120885-895$.

Venkatachalapathy R, Rajeswari V, Basavaiah N and Balasubramanian T 2013 Environmental magnetic studies on surface sediments: A proxy for metal and hydrocarbon contamination; Int. J. Environ. Sci. Technol., doi: 10.1007/s13762-013-0355-4 (in press).

Verosub K L and Roberts A P 1995 Environmental magnetism: Past, present and future; J. Geophys. Res. 100 2175-2192.

Vijayalakshmi C S, Srinivasan P, Murthy S G N, Trivedi D and Nair R R 2010 Granularity and textural analysis as a proxy for extreme wave events in southeast coast of India; J. Earth Syst. Sci. 119 297-305.

Walden J, Smith J P and Oldfield F 1999 Environmental magnetism: A practical guide, Quaternary Research Association Technical Guide, vol. 6, 243p.

Wassmer P, Schneider J-L, Fonfrege A-V, Lavigne F, Paris R and Gomez C 2010 Use of anisotropy of magnetic susceptibility (AMS) in the study of tsunami deposits: Application to the 2004 deposits on the eastern coast of Banda Aceh, North Sumatra, Indonesia; Marine Geol. 275 255-272.

Yeh H, Chadha R K, Francis M, Katada T, Latha G, Peterson C, Raghuraman G and Singh J P 2006 Tsunami runup survey along the southeast Indian coast; Earthquake Spectra 22 S173-S183. 